\title{
Carbon footprint analysis through constructing a multi-region input-output table: a case study of Japan
}

\author{
Ryoji Hasegawa ${ }^{1 *}$, Shigemi Kagawa ${ }^{2}$ and Makiko Tsukui ${ }^{3}$
}

\footnotetext{
* Correspondence: hasegawa@oiu.jp ${ }^{1}$ Faculty of Global Business, Osaka International University, 6-21-57 Tohdacho, 570-8555 Moriguchi, Osaka, Japan

Full list of author information is available at the end of the article
}

\begin{abstract}
In line with recent trends toward decentralization, prefectural and municipal governments in Japan are becoming increasingly involved with managing global warming in their regions. As a result, there is a new need to estimate the environmental effects of regional economic activities, which can be used to establish effective energy policies at the regional level. However, the details of these effects remain unclear due to a lack of basic data. In this paper, we construct an original multi-region input-output (MRIO) table based on interregional shipments among Japan's 47 prefectures; this is done using the prefectures' single-region input-output (SRIO) tables and by applying a non-survey technique. We use the constructed MRIO table, which we make freely available online, to estimate the carbon footprint and carbon leakage of every region and consider the structure of emissions at the regional level from the standpoints of consumer and producer responsibility. The results reveal that production-based emissions often differ significantly from consumption-based emissions. In addition, the regional-level ratio of carbon leakage to carbon footprint is $51.7 \%$ on average and ranges from 34.8 to $79.8 \%$. Furthermore, the effects of economic activity in and around Tokyo in terms of $\mathrm{CO}_{2}$ emissions and leakage vary across regions.

JEL classification: Q54, R11, R15

Keywords: Carbon footprint; Multi-region input-output table; Carbon leakage; Economic leakage
\end{abstract}

\section{Background}

In 1998, the Japanese government encouraged municipalities to voluntarily seek solutions to global warming by enacting the Law Concerning the Promotion of Measures to Cope with Global Warming. As a result, many governments at the prefecture and municipality levels have become increasingly concerned about global warming issues and the need for appropriate regional policies.

All prefectural governments in Japan estimate regional greenhouse gas (GHG) emissions according to guidelines established by the Ministry of the Environment and publish concrete plans for GHG reduction. All prefectures also set up departments or divisions focused on environmental problems. In contrast, many municipalities, especially smaller ones, do not have designated staff focused on environmental administration. Therefore, prefectures play a more important role than municipalities in addressing global warming at the sub-national level.

\section{Springer}

(c) 2015 Hasegawa et al. This is an Open Access article distributed under the terms of the Creative Commons Attribution License (http://creativecommons.org/licenses/by/4.0), which permits unrestricted use, distribution, and reproduction in any medium, provided the original work is properly credited. 
As a prerequisite to framing appropriate environmental policies at the regional level, it is necessary to quantify each region's environmental burden. For instance, Hasegawa [1] estimated $\mathrm{CO}_{2}$ emissions among industries at the prefectural level in Japan in 1995 and 2000 and clarified the differences in emissions structures among regions and industries. Kudoh et al. [2] estimated $\mathrm{CO}_{2}$ emissions from vehicles at the municipal level in Japan and investigated policies for emissions reduction, taking into consideration regional characteristics. Most studies, including these two, confine their accounting to direct emissions in a region, excluding emissions related to electricity.

When considering the scope of emissions for which a region is responsible, two types of regional emissions can be identified. The first, "production-based" emissions, refers to the $\mathrm{CO}_{2}$ actually emitted by industries in a region as a result of production activities. The other is "consumption-based" emissions: the $\mathrm{CO}_{2}$ emissions that were required to satisfy final demand for goods and services by a region's population as well as those emitted directly by households from private automobiles or for heating.

Production-based emissions can generally be identified by simply summing direct emissions; however, accounting for consumption-based emissions requires considering not only direct but also indirect emissions. Consumption-based emissions, excluding direct emissions from households, are frequently referred to as a "carbon footprint."

A carbon footprint does not necessarily align with the direct emissions in a given region due to regional characteristics such as the locations of industrial production and housing, the pattern of interregional transactions, and the division of labor. In general, the smaller the region examined, the larger the difference between its carbon footprint and its direct emissions. The portion of a carbon footprint that is generated outside a region can be interpreted as the region's "carbon leakage ${ }^{1}$." These amounts have grown recently because of the increasing division of labor and more frequent interregional transactions. Large levels of carbon leakage make it difficult to estimate carbon footprints.

Accurate identification of carbon footprints by estimating carbon leakage among regions and industries is necessary, however, to establish effective policies to counter global warming at the regional level. An input-output (IO) model, especially a multi-region IO (MRIO) $)^{2}$ model, is one useful tool for carbon footprint analysis ${ }^{3}$. Several studies have verified the usefulness of MRIO models in estimating comprehensive environmental loads. For instance, Vringer et al. [3] estimated land use and GHG emissions induced by household consumption in the Netherlands by using different models, including an MRIO model, and investigated the differences in empirical results among models. The authors concluded that an MRIO model could comprehensively estimate environmental loads induced by final demand and proposed a hybrid multi-region (HMR) method that linked MRIO models with process analysis.

Numerous studies have analyzed carbon footprints by using MRIO tables and focusing on the environmental impact of international trade. For instance, Ackerman et al. [4] investigated how trade between Japan and the USA influences the volume of global $\mathrm{CO}_{2}$ emissions by changing the trading structures in MRIO models. Su and Ang [5] calculated exports and imports of $\mathrm{CO}_{2}$ using the Asian International Input-Output Table compiled by the Institute of Developing Economies Japan External Trade Organization (IDE- 
JETRO) in order to reveal the process through which emissions embodied in trade are distributed within a country's final demand through feedback effects.

Although carbon footprint analyses tend to adopt an international perspective, several studies, such as those by Su and Ang [6] and Zhou and Imura [7], have used MRIO models at the sub-national level to investigate comprehensive environmental impacts. Both of these studies focused on spatial variation and aggregation related to environmental impacts and conducted environmental analyses by using IO tables compiled by IED-JETRO for eight regions of China. Notably, Su and Ang [6] argued that it is essential to consider spatial aggregation in a country with large regional variations in emissions structures, particularly for large countries such as China.

Most studies, including the aforementioned, use officially compiled, existing MRIO tables; as a result, there are few regions for which the proposed models are applicable. It is more useful and flexible to construct an original MRIO table, using the wellestablished method ${ }^{4}$, according to the objective of the study. This paper thus constructs an original MRIO table linking all of Japan's 47 prefectures, using this process to both highlight issues involved with constructing MRIO tables and propose a construction method that is widely applicable in many settings. This paper also undertakes a regional analysis of carbon footprints using the constructed MRIO table; the results are shown to have important implications for climate policy.

The rest of the paper is organized as follows. In Section 2, we explain the method used for constructing the MRIO table based on inter-prefecture shipments among all prefectures in Japan. In Section 3, we develop a $\mathrm{CO}_{2}$ emissions model based on the constructed MRIO table. In Section 4, we estimate the carbon footprints and carbon leakages for all prefectures in 2005 and analyze the results. Finally, we discuss prefectural emissions responsibilities by considering both consumer and producer responsibilities $^{5}$; this allows us to identify significant outstanding issues in sub-national environmental policy.

\section{Construction of an MRIO table}

\subsection{Background}

Regional IO tables can be classified into single-region input-output (SRIO) tables and MRIO tables. While SRIO tables endogenously identify transactions among industrial sectors within a single region, MRIO tables endogenously consider the transactions between multiple regions and reveal interrelationships among regions. MRIO tables can therefore comprehensively calculate economic repercussions by considering the effects inside and outside a region as well as the rebound effects. SRIO tables underestimate economic repercussions because they cannot account for all of the effects that are included in an MRIO table. It is thus desirable to use MRIO tables when analyzing carbon footprints, as carbon leakage largely depends on economic repercussions.

Although Japan's Ministry of Economy, Trade, and Industry (METI) compiles an interregional IO table for Japan that is segmented into nine regions, this segmentation is not thorough enough for conducting a detailed analysis of the regional implications of emissions policies. A district is not simply a large monolithic area but rather includes 
many local governments that are diverse in terms of emissions sources, as we later show in our analysis.

It would be almost impossible to construct a complete interregional table from scratch, as proposed by Isard [8], because this requires an enormous amount of data on interregional trade that is unavailable. Most studies have instead constructed simplified MRIO tables, typically of the Chenery-Moses type, using limited data in an operational framework. Ishikawa and Miyagi [9], however, attempted to construct interregional IO tables that covered all prefectures in Japan; in the process, the authors noted certain issues concerning METI's compilation of interregional IO tables. Ishikawa and Miyagi focused on accurately estimating interregional trade coefficients using a large quantity of interregional trade data as well as IO data and adjusted the estimated coefficients to make the total output of all prefectures consistent with that of Japan as a whole; they were thus able to propose a sophisticated method for constructing interregional IO tables. In their resulting table, industrial sectors were aggregated into 45 sectors, presumably due to data limitations.

The 45-sector classification groups together industries with significantly different emissions intensities as one sector. For example, "ceramic, stone, and clay products," a single sector in the classification, includes both cement and glass production, despite the fact that cement's emissions intensity is more than 20 times that of glass. The aggregation level significantly affects the results of the IO calculations, particularly when emissions intensities differ largely among the subsector's industries; Jacobsen [10] illustrated this by comparing results from 27 -sector IO calculations to 117 -sector results. A more detailed classification is thus required for accurate carbon footprint analysis.

This paper constructs an original MRIO table with classification into over 45 sectors using only the data available from SRIO tables; we are thus able to demonstrate a method that requires less data and thus can be widely applied in different countries. We do this by taking advantage of SRIO tables compiled by each prefectural office; such tables are available for all prefectures in Japan. Using these, we construct an MRIO table for 2005 consisting of every prefecture in Japan by applying a non-survey technique.

Figure 1 shows the names and locations of Japan's prefectures. As there are 47 prefectures in Japan, the constructed IO table consists of 47 regions. In the MRIO tables presented in this paper, we have used the SRIO tables, which offer the most detailed sector classification available, to compile industrial sectors with the highest level of detail possible. As a result, we consider 80 industrial sectors, which corresponds to the middle classification in the SRIO table compiled by METI, as shown in Table 1.

\subsection{Table construction methods}

Figure 2 shows the framework of the MRIO table constructed in this paper. The grey cells indicate transactions that can be identified from the prefectural SRIO tables, while those in the other cells must be estimated. Data for the output vector (x), value-added vector $(\mathbf{v})$, final demand vector $(\mathbf{f})$, and intermediate demand matrix $(\mathbf{Z})$ in Fig. 2 is taken directly from the prefectural SRIO tables, as is that for the foreign export vector 
(33) Okayama

(34) Hiroshima

(35) Yamaguchi

(36) Tokushima

(37) Kagawa

(38) Ehime

(39) Kochi

(40) Fukuoka

(41) Saga

(42) Nagasaki

(43) Kumamoto

(44) Oita

(45) Miyazaki

(46) Kagoshima

(47) Okinawa

(16) Toyama

(31) Tottori

(32) Shimane

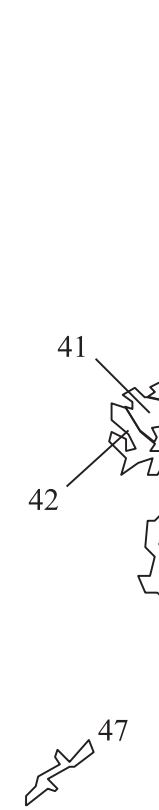

Fig. 1 Prefectures in Japan

(e), domestic export vector (d), foreign import vector (m), and domestic import vector $(\mathbf{n})^{6}$. Therefore, the balance equation is expressed using the available data as follows:

$$
x_{i}^{r}=\sum_{j} z_{i j}^{r}+f_{i}^{r}+e_{i}^{r}+d_{i}^{r}-m_{i}^{r}-n_{i}^{r}
$$

In Eq. (1), $x_{i}^{r}, z_{i j}^{r}, f_{i}^{r}, e_{i}^{r}, d_{i}^{r}, m_{i}^{r}$, and $n_{i}^{r}$ are elements of $\mathbf{x}, \mathbf{z}, \mathbf{f}, \mathbf{e}, \mathbf{d}, \mathbf{m}$, and $\mathbf{n}$, respectively; superscripts and subscripts denote prefectures and industries, respectively.

The prefectural SRIO tables are in the competitive foreign import (and domestic import) form. This paper divides foreign import volumes into intermediate and final demand by using foreign import coefficients; the same is done for domestic imports. 
Table 1 Industrial sectors included in the MRIO table

\begin{tabular}{|c|c|c|c|c|c|c|c|}
\hline (1) & $\begin{array}{l}\text { Agriculture, } \\
\text { forestry, and } \\
\text { fisheries }\end{array}$ & (21) & Medicaments & (41) & $\begin{array}{l}\text { Office machines and } \\
\text { machinery for service } \\
\text { industries }\end{array}$ & (61) & $\begin{array}{l}\text { Gas, steam, and hot } \\
\text { water supply }\end{array}$ \\
\hline (2) & Metal ores & (22) & $\begin{array}{l}\text { Petroleum refinery } \\
\text { products }\end{array}$ & (42) & $\begin{array}{l}\text { Household electric and } \\
\text { electronic appliances }\end{array}$ & (62) & $\begin{array}{l}\text { Water supply and } \\
\text { other sanitary } \\
\text { services }\end{array}$ \\
\hline (3) & Nonmetal ores & (23) & Coal products & (43) & $\begin{array}{l}\text { Electronic computing } \\
\text { equipment and } \\
\text { accessory equipment }\end{array}$ & (63) & Trade \\
\hline (4) & $\begin{array}{l}\text { Coal, crude } \\
\text { petroleum, and } \\
\text { natural gas }\end{array}$ & (24) & Plastic products & (44) & $\begin{array}{l}\text { Communication } \\
\text { equipment }\end{array}$ & (64) & $\begin{array}{l}\text { Financial service and } \\
\text { insurance }\end{array}$ \\
\hline (5) & Food and tobacco & (25) & Rubber products & (45) & $\begin{array}{l}\text { Applied electronic } \\
\text { equipment and electric } \\
\text { measuring instruments }\end{array}$ & (65) & $\begin{array}{l}\text { Real estate agencies, } \\
\text { managers, and rent }\end{array}$ \\
\hline (6) & Drinks & (26) & $\begin{array}{l}\text { Glass and glass } \\
\text { products }\end{array}$ & (46) & $\begin{array}{l}\text { Semiconductor devices } \\
\text { and integrated circuits }\end{array}$ & (66) & $\begin{array}{l}\text { House rent (imputed } \\
\text { house rent) }\end{array}$ \\
\hline (7) & Fabric & (27) & $\begin{array}{l}\text { Cement and } \\
\text { cement products }\end{array}$ & (47) & Electronic components & $(67)$ & Transport \\
\hline (8) & $\begin{array}{l}\text { Apparel and other } \\
\text { ready-made textile } \\
\text { products }\end{array}$ & (28) & $\begin{array}{l}\text { Pottery, china, and } \\
\text { earthenware }\end{array}$ & (48) & $\begin{array}{l}\text { Industrial heavy } \\
\text { electrical equipment }\end{array}$ & (68) & Telecommunication \\
\hline (9) & $\begin{array}{l}\text { Timber and } \\
\text { wooden products }\end{array}$ & (29) & $\begin{array}{l}\text { Miscellaneous } \\
\text { ceramic, stone and } \\
\text { clay products }\end{array}$ & (49) & $\begin{array}{l}\text { Other electrical } \\
\text { equipment }\end{array}$ & (69) & Broadcasting \\
\hline (10) & $\begin{array}{l}\text { Wooden furniture } \\
\text { and accessories }\end{array}$ & (30) & $\begin{array}{l}\text { Pig iron and crude } \\
\text { steel }\end{array}$ & (50) & Motor vehicles & (70) & Information service \\
\hline (11) & Pulp and paper & (31) & Steel & (51) & Other motor vehicles & (71) & Internet services \\
\hline (12) & $\begin{array}{l}\text { Converted paper } \\
\text { products }\end{array}$ & (32) & $\begin{array}{l}\text { Cast and forged } \\
\text { materials }\end{array}$ & (52) & Steel ships and repair & (72) & $\begin{array}{l}\text { Video and data } \\
\text { entry }\end{array}$ \\
\hline (13) & $\begin{array}{l}\text { Publishing and } \\
\text { printing }\end{array}$ & (33) & $\begin{array}{l}\text { Other iron or steel } \\
\text { products }\end{array}$ & (53) & $\begin{array}{l}\text { Other transportation } \\
\text { equipment and repair }\end{array}$ & (73) & Advertising services \\
\hline (14) & Chemical fertilizer & (34) & Nonferrous metals & (54) & Precision machinery & (74) & $\begin{array}{l}\text { Public } \\
\text { administration }\end{array}$ \\
\hline (15) & $\begin{array}{l}\text { Industrial inorganic } \\
\text { chemicals }\end{array}$ & (35) & $\begin{array}{l}\text { Nonferrous metal } \\
\text { products }\end{array}$ & (55) & $\begin{array}{l}\text { Miscellaneous } \\
\text { manufacturing products }\end{array}$ & (75) & $\begin{array}{l}\text { Education and } \\
\text { research institute }\end{array}$ \\
\hline (16) & $\begin{array}{l}\text { Petroleum } \\
\text { chemical basic } \\
\text { products }\end{array}$ & (36) & $\begin{array}{l}\text { Metal products for } \\
\text { construction and } \\
\text { architecture }\end{array}$ & (56) & Reuse and recycling & (76) & $\begin{array}{l}\text { Medical service, } \\
\text { health, social } \\
\text { security, and nursing } \\
\text { care }\end{array}$ \\
\hline (17) & $\begin{array}{l}\text { Organic chemical } \\
\text { products }\end{array}$ & (37) & $\begin{array}{l}\text { Other metal } \\
\text { products }\end{array}$ & (57) & $\begin{array}{l}\text { Construction and repair } \\
\text { of construction }\end{array}$ & (77) & $\begin{array}{l}\text { Goods renting/ } \\
\text { leasing }\end{array}$ \\
\hline (18) & Resin & (38) & $\begin{array}{l}\text { General industrial } \\
\text { machinery }\end{array}$ & (58) & Public construction & (78) & $\begin{array}{l}\text { Other business } \\
\text { services }\end{array}$ \\
\hline (19) & Chemical fiber & (39) & $\begin{array}{l}\text { Special industrial } \\
\text { machinery }\end{array}$ & (59) & $\begin{array}{l}\text { Other civil engineering } \\
\text { and construction }\end{array}$ & (79) & Personal service \\
\hline (20) & $\begin{array}{l}\text { Final chemical } \\
\text { products }\end{array}$ & (40) & $\begin{array}{l}\text { Other general } \\
\text { machines and parts }\end{array}$ & (60) & Electric power & (80) & Other \\
\hline
\end{tabular}

Foreign import coefficients $\left(M_{i}^{r}\right)$ and domestic coefficients $\left(N_{i}^{r}\right)$ are obtained using Eqs. (2) and (3):

$$
M_{i}^{r}=\frac{m_{i}^{r}}{\sum_{j} z_{i j}^{r}+f_{i}^{r}}
$$




\begin{tabular}{|c|c|c|c|c|c|c|c|c|}
\hline & \multicolumn{3}{|c|}{ Intermediate demand } & \multicolumn{3}{|c|}{ Final demand } & \multirow{2}{*}{$\begin{array}{l}\text { Foreign } \\
\text { export }\end{array}$} & \multirow{2}{*}{ Output } \\
\hline & Region A & Region B & Region $\mathrm{C}$ & Region A & Region B & Region C & & \\
\hline 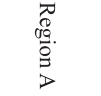 & $\begin{array}{c}\left(\mathbf{I}-\mathbf{M}^{\mathrm{A}}-\mathbf{N}^{\mathrm{A}}\right) \\
\mathbf{Z}^{\mathrm{A}}\end{array}$ & & & $\begin{array}{c}\left(\mathbf{I}-\mathbf{M}^{\mathrm{A}}-\mathrm{N}^{\mathrm{A}}\right) \\
\mathbf{f}^{\mathbf{A}}\end{array}$ & & & $e^{A}$ & $x^{A}$ \\
\hline 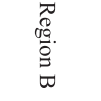 & & $\begin{array}{c}\left(\mathrm{I}-\mathrm{M}^{\mathrm{B}}-\mathrm{N}^{\mathrm{B}}\right) \\
\mathbf{Z}^{\mathrm{B}}\end{array}$ & & & $\begin{array}{c}\left(\mathrm{I}-\mathrm{M}^{\mathrm{B}}-\mathrm{N}^{\mathrm{B}}\right) \\
\mathbf{f}^{\mathrm{B}}\end{array}$ & & $e^{B}$ & $\mathbf{x}^{\mathbf{B}}$ \\
\hline 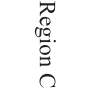 & & & $\begin{array}{c}\left(\mathrm{I}-\mathrm{M}^{\mathrm{C}}-\mathrm{N}^{\mathrm{C}}\right) \\
\mathrm{Z}^{\mathrm{C}}\end{array}$ & & & $\begin{array}{c}\left(\mathrm{I}-\mathrm{M}^{\mathrm{C}}-\mathrm{N}^{\mathrm{C}}\right) \\
\mathrm{f}^{\mathrm{C}}\end{array}$ & $e^{c}$ & $x^{C}$ \\
\hline $\begin{array}{c}\text { Domestic } \\
\text { input }\end{array}$ & $\begin{array}{c}(11 \cdots 1) \times \\
\left(I-M^{A}\right) Z^{A}\end{array}$ & $\begin{array}{c}(11 \cdots 1) \times \\
\left(I-M^{B}\right) Z^{B}\end{array}$ & $\begin{array}{c}(11 \cdots 1) \times \\
\left(I-M^{C}\right) Z^{C}\end{array}$ & $\begin{array}{c}(11 \cdots 1) \times \\
\left(I-M^{A}\right) f^{A}\end{array}$ & $\begin{array}{r}(11 \cdots 1) \times \\
\left(I-M^{B}\right) f^{B}\end{array}$ & $\begin{array}{c}(11 \cdots 1) \times \\
\left(I-M^{C}\right) f^{C}\end{array}$ & & \\
\hline $\begin{array}{c}\text { Foreign } \\
\text { import }\end{array}$ & $\begin{array}{c}(11 \cdots 1) \times \\
M^{A} Z^{A}\end{array}$ & $\begin{array}{c}(11 \cdots 1) \times \\
M^{B} Z^{B}\end{array}$ & $\begin{array}{c}(11 \cdots 1) \times \\
M^{\mathrm{C}} \mathbf{Z}^{\mathrm{C}} \\
\end{array}$ & $\begin{array}{c}(11 \cdots 1) \times \\
M^{A} f^{A}\end{array}$ & $\begin{array}{c}(11 \cdots 1) \times \\
M^{B} f^{B}\end{array}$ & $\begin{array}{c}(11 \cdots 1) \times \\
M^{C} f^{C}\end{array}$ & & \\
\hline $\begin{array}{l}\text { Value- } \\
\text { added }\end{array}$ & $\mathbf{v}^{A}$ & $\mathbf{v}^{\mathrm{B}}$ & $\mathbf{v}^{\mathrm{c}}$ & & & & & \\
\hline Output & $x^{A}$ & $x^{B}$ & $x^{c}$ & & & & & \\
\hline
\end{tabular}

$$
N_{i}^{r}=\frac{n_{i}^{r}}{\sum_{j} z_{i j}^{r}+f_{i}^{r}}
$$

By using $\mathbf{M}$ and $\mathbf{N}$, which are the diagonal matrices of $M_{i}^{r}$ and $N_{i}^{r}$, respectively, we can identify intraregional transactions (the elements along the diagonal), domestic inputs, and foreign imports within both intermediate and final demand, as shown in Fig. 2.

$$
\begin{aligned}
& z_{i j}^{r r}=\left(1-M_{i}^{r}-N_{i}^{r}\right) z_{i j}^{r} \\
& f_{i j}^{r r}=\left(1-M_{i}^{r}-N_{i}^{r}\right) f_{i j}^{r}
\end{aligned}
$$

Equations (4) and (5) indicate intraregional transactions for intermediate demand and final demand, respectively. Using these two equations, we can divide both intermediate and final demand into internal supply, foreign imports, and domestic imports, as shown in Eqs. (6) and (7).

$$
\begin{aligned}
& z_{i j}^{r}=z_{i j}^{r r}+M_{i}^{r} z_{i j}^{r}+N_{i}^{r} z_{i j}^{r} \\
& f_{i}^{r}=f_{i}^{r r}+M_{i}^{r} f_{i}^{r}+N_{i}^{r} f_{i}^{r}
\end{aligned}
$$

Figure 3 shows only the transactions that must be estimated, which are extracted from Fig. 2; as such, it can be regarded as a matrix of domestic trade among regions. The diagonal elements of the matrix are set to zero for both intermediate and final demand because intraregional transactions are excluded. The matrix's row and column sums correspond to total domestic exports and imports in each region, as obtained from the prefectural SRIO tables.

This paper applies the RAS method, using total domestic exports and imports in each region as the control totals to estimate each element of the matrix shown in Fig. 3. In other words, we simultaneously estimate trade flows to meet intermediate and final 


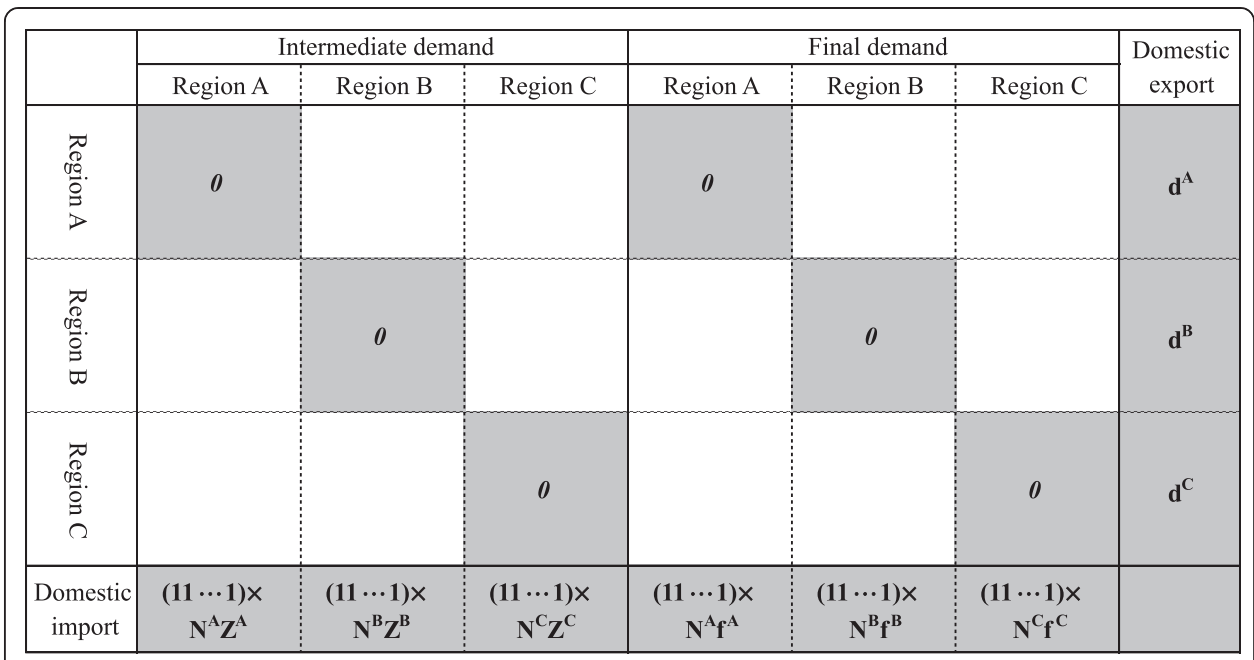

Fig. 3 Matrix of domestic trade among regions

demand by applying the RAS method to a rectangular matrix. Although the RAS method is most commonly used to update or estimate a square input coefficient matrix, it is frequently applied to other types of matrices. For example, Hasegawa [1] constructed energy flow matrices for Japan consisting of 33 sectors and 47 prefectures by applying the RAS method modified for a rectangular matrix, and Lahr and Mesnard [11] explained the application of the RAS procedure to a rectangular matrix.

In the RAS calculation, a matrix for approximation is required. We construct the approximation matrix by distributing total domestic imports (i.e., NZ and Nf) for each column across the 46 prefectures according to the ratio of the corresponding prefecture's monetary output to the total (the sum for all 46 prefectures). The elements of the approximation matrix are expressed in Eqs. (8) and (9).

$$
\begin{aligned}
& z_{i j}^{r s}=\frac{x_{i}^{s}}{\sum_{s}^{46} x_{i}^{s}} N_{i}^{r} z_{i j}^{r} \text { for } s \neq r \\
& f_{i}^{r s}=\frac{x_{i}^{s}}{\sum_{s}^{46} x_{i}^{s}} N_{i}^{r} f_{i}^{r} \text { for } s \neq r
\end{aligned}
$$

The diagonal elements of the approximation matrix are set to zero ${ }^{7}$ for consistency with Fig. 3. As a result of the RAS calculation, the diagonal parts are estimated to be zero and the other estimated elements are consistent in that the sums of the row and column elements are equal to total domestic exports and imports, respectively.

The economic interpretation of the ordinal RAS procedure is that a matrix of intermediate transactions is adjusted to consider substitution and fabrication effects ${ }^{8}$. This arises because we use the RAS method on an interregional trade matrix including intermediate and final demand; the RAS procedure thus involves not only the two effects but also the change of the trade outlet and the substitution of demand between selfsupplied products and imports. It is assumed that the former occurs via adjustments to the row quantities and the latter via adjustments to the column quantities.

The constructed table is available online as Additional files ${ }^{9} 1,2,3,4,5,6,7,8$, and 9 . 


\section{Carbon footprint analysis method}

In this section, we explain the method used for carbon footprint analysis based on the MRIO table, which was constructed using the method explained in the previous section. The output balance equation in the row direction is expressed via Eq. (10) because domestic exports and imports are endogenous in the MRIO table.

$$
\underbrace{\left[\begin{array}{c}
\mathbf{x}^{1} \\
\mathbf{x}^{2} \\
\vdots \\
\mathbf{x}^{\mathbf{R}}
\end{array}\right]}_{\mathbf{X}}=\underbrace{\left[\begin{array}{cccc}
\mathbf{A}^{\mathbf{1 1}} & \mathbf{A}^{\mathbf{1 2}} & \cdots & \mathbf{A}^{1 \mathbf{R}} \\
\mathbf{A}^{21} & \mathbf{A}^{22} & \cdots & \mathbf{A}^{2 \mathbf{R}} \\
\vdots & \vdots & \ddots & \vdots \\
\mathbf{A}^{\mathbf{R} 1} & \mathbf{A}^{\mathbf{R} 2} & \cdots & \mathbf{A}^{\mathbf{R R}}
\end{array}\right]}_{\mathbf{A}} \underbrace{\left[\begin{array}{c}
\mathbf{x}^{1} \\
\mathbf{x}^{2} \\
\vdots \\
\mathbf{x}^{\mathbf{R}}
\end{array}\right]}_{\mathbf{X}}+\underbrace{\left[\begin{array}{c}
\mathbf{f}^{11} \\
\mathbf{f}^{21} \\
\vdots \\
\mathbf{f}^{\mathbf{R} 1}
\end{array}\right]}_{\mathbf{f}^{1}}+\cdots+\underbrace{\left[\begin{array}{c}
\mathbf{f}^{1 \mathbf{R}} \\
\mathbf{f}^{2 \mathbf{R}} \\
\vdots \\
\mathbf{f}^{\mathbf{R R}}
\end{array}\right]}_{\mathbf{f}^{\mathrm{R}}}+\underbrace{\left[\begin{array}{c}
\mathbf{e}^{1} \\
\mathbf{e}^{2} \\
\vdots \\
\mathbf{e}^{\mathbf{R}}
\end{array}\right]}_{\mathbf{e}}
$$

In Equation (10), $\mathbf{x}, \mathbf{A}, \mathbf{f}^{\mathbf{r}}$, and $\mathbf{e}$ are the output vector, input coefficient matrix, regional final demand vector, and foreign export vector, respectively.

As shown in Fig. 2, the constructed IO table excludes foreign imports $(\mathbf{m})$ in the endogenous sector and the final demand sector by subtracting them from the column direction in a lump sum. Therefore, the foreign import vector is originally excluded from Eq. (10). We develop Eq. (10) into Eq. (11), below.

$$
\mathbf{x}=(\mathbf{I}-\mathbf{A})^{-1}\left(\mathbf{f}^{\mathbf{1}}+\cdots+\mathbf{f}^{\mathbf{R}}+\mathbf{e}\right)
$$

Next, we estimate both production-based emissions $\left(\mathbf{q}_{\mathbf{P}}^{\mathbf{r}}\right)$ and consumption-based emissions $\left(\mathbf{q}_{\mathbf{C}}^{\mathbf{r}}\right)$ by linking the dataset of emissions coefficients in industries (c) and direct household emissions coefficients $(\mathbf{h})^{10}$ with Eq. (11).

$$
\begin{aligned}
& \mathbf{q}_{\mathbf{P}}^{\mathbf{r}}=\mathbf{C x}^{\mathbf{r}} \\
& \mathbf{q}_{\mathbf{C}}^{\mathbf{r}}=\underbrace{\mathbf{C}(\mathbf{I}-\mathbf{A})^{-1} \mathbf{f}^{\mathbf{r}}}_{\text {Carbon footprint }}+\underbrace{\mathrm{Hf}^{\mathrm{r}}}_{\text {Direct emissions in households }}
\end{aligned}
$$

In Eqs. (12) and (13), $\mathbf{C}$ and $\mathbf{H}$ are diagonal matrixes with emissions coefficients $\mathbf{c}$ and $\mathbf{h}$, respectively. Equation (12) refers to production-based emissions-i.e., the $\mathrm{CO}_{2}$ emitted to produce domestic final demand goods and exports. Equation (13) then considers consumption-based emissions, including indirect emissions needed to satisfy regional final demand, which is the first term on the right-hand side, and direct emissions of households from private vehicles or heating, which is the second term on the right-hand side.

This paper defines the first term on the right-hand side of Eq. (13) as a carbon footprint and investigates carbon leakage among industries and prefectures. Equation (13) does not include the carbon footprints generated in foreign countries to produce Japan's foreign imports: we focus on analyzing carbon footprints and leakage for domestic emissions only.

\section{Results}

\subsection{Total emissions at the prefectural level}

First, we investigate total emissions at the prefectural level. Table 2 shows total and per capita emissions for each prefecture, broken down into production and consumption causes. In terms of total emissions, Chiba (12) has the largest volume of production- 
Table 2 Production- and consumption-based emissions in each prefecture

\begin{tabular}{|c|c|c|c|c|c|}
\hline & & \multicolumn{2}{|c|}{ Emissions from production } & \multicolumn{2}{|c|}{ Emissions from consumption } \\
\hline & & Total & Per capita & Total & Per capita \\
\hline & & $(\mathrm{Mt} \mathrm{CO})$ & $(\mathrm{t} \mathrm{CO})_{2}$ & $(\mathrm{Mt} \mathrm{CO})$ & $\left(\mathrm{t} \mathrm{CO}_{2}\right)$ \\
\hline (1) & Hokkaido & $44(10)$ & $7.8(25)$ & $48(5)$ & $8.5(10)$ \\
\hline (2) & Aomori & $10(31)$ & $7.1(31)$ & $11(29)$ & $7.5(33)$ \\
\hline (3) & Iwate & $7(40)$ & $5.3(43)$ & $10(31)$ & $7.6(30)$ \\
\hline (4) & Miyagi & $17(21)$ & $7.1(30)$ & $18(15)$ & $7.6(26)$ \\
\hline (5) & Akita & $8(38)$ & $7.2(29)$ & $9(34)$ & $8.1(18)$ \\
\hline (6) & Yamagata & $6(43)$ & $5.1(46)$ & $9(35)$ & $7.6(29)$ \\
\hline (7) & Fukushima & $49(7)$ & $23.4(2)$ & $16(17)$ & $7.7(25)$ \\
\hline (8) & Ibaraki & $51(6)$ & $17.0(6)$ & $25(11)$ & $8.5(9)$ \\
\hline (9) & Tochigi & $12(29)$ & $5.8(40)$ & $15(20)$ & $7.4(36)$ \\
\hline (10) & Gumma & $13(27)$ & $6.3(35)$ & $14(22)$ & $6.9(43)$ \\
\hline (11) & Saitama & $30(15)$ & $4.3(47)$ & $47(6)$ & $6.7(48)$ \\
\hline (12) & Chiba & $91(1)$ & $15.0(8)$ & $44(7)$ & $7.3(38)$ \\
\hline (13) & Tokyo & $87(2)$ & $6.9(33)$ & $157(1)$ & $12.4(1)$ \\
\hline (14) & Kanagawa & $65(4)$ & $7.4(26)$ & $73(2)$ & $8.3(12)$ \\
\hline (15) & Niigata & $33(13)$ & $13.5(10)$ & $20(13)$ & $8.4(11)$ \\
\hline (16) & Toyama & $12(30)$ & $10.4(17)$ & $8(39)$ & $7.4(37)$ \\
\hline (17) & Ishikawa & $9(34)$ & $8.0(24)$ & $11(30)$ & $9.0(4)$ \\
\hline (18) & Fukui & $20(19)$ & $24.4(1)$ & $7(43)$ & $8.0(21)$ \\
\hline (19) & Yamanashi & $5(46)$ & $5.3(42)$ & $7(42)$ & $7.9(22)$ \\
\hline (20) & Nagano & $16(22)$ & $7.3(28)$ & $16(18)$ & $7.2(41)$ \\
\hline (21) & Gifu & $15(25)$ & $7.3(27)$ & $14(21)$ & $6.8(46)$ \\
\hline (22) & Shizuoka & $32(14)$ & $8.4(23)$ & $31(10)$ & $8.3(14)$ \\
\hline (23) & Aichi & 79 (3) & $10.9(15)$ & $66(4)$ & $9.0(3)$ \\
\hline (24) & Mie & $22(18)$ & $11.9(11)$ & $19(14)$ & $10.0(2)$ \\
\hline (25) & Shiga & $7(41)$ & $5.2(45)$ & $12(26)$ & $8.6(8)$ \\
\hline (26) & Kyoto & $15(24)$ & $5.8(41)$ & $18(16)$ & $6.7(47)$ \\
\hline (27) & Osaka & $57(5)$ & $6.4(34)$ & $72(3)$ & $8.1(17)$ \\
\hline (28) & Hyogo & $47(8)$ & $8.5(22)$ & $40(8)$ & $7.2(39)$ \\
\hline (29) & Nara & $5(44)$ & $3.6(48)$ & $10(33)$ & $6.8(44)$ \\
\hline (30) & Wakayama & $15(23)$ & 14.9 (9) & $9(38)$ & $8.3(15)$ \\
\hline (31) & Tottori & $4(47)$ & 5.9 (39) & $5(47)$ & 7.9 (23) \\
\hline (32) & Shimane & $8(39)$ & $10.6(16)$ & $6(45)$ & $8.1(19)$ \\
\hline (33) & Okayama & $35(12)$ & $17.9(4)$ & 15 (19) & $7.9(24)$ \\
\hline (34) & Hiroshima & $45(9)$ & $15.6(7)$ & $25(12)$ & $8.7(6)$ \\
\hline (35) & Yamaguchi & $26(16)$ & $17.1(5)$ & $11(27)$ & $7.5(31)$ \\
\hline (36) & Tokushima & $9(36)$ & $11.4(13)$ & $7(41)$ & $8.7(7)$ \\
\hline (37) & Kagawa & $9(35)$ & $9.2(18)$ & $8(40)$ & $7.6(27)$ \\
\hline (38) & Ehime & $17(20)$ & $11.6(12)$ & $13(24)$ & $9.0(5)$ \\
\hline (39) & Koch & $5(45)$ & $6.2(37)$ & $7(44)$ & $8.2(16)$ \\
\hline (40) & Fukuoka & $43(11)$ & $8.5(21)$ & $36(9)$ & $7.1(42)$ \\
\hline (41) & Saga & $10(33)$ & $11.1(14)$ & $6(46)$ & $6.8(45)$ \\
\hline (42) & Nagasaki & $13(26)$ & $8.9(20)$ & $11(28)$ & $7.6(28)$ \\
\hline
\end{tabular}


Table 2 Production- and consumption-based emissions in each prefecture (Continued)

\begin{tabular}{llllll}
\hline$(43)$ & Kumamoto & $10(32)$ & $5.2(44)$ & $13(23)$ & $7.2(40)$ \\
$(44)$ & Oita & $24(17)$ & $19.5(3)$ & $9(37)$ & $7.5(35)$ \\
$(45)$ & Miyazaki & $7(42)$ & $6.1(38)$ & $9(36)$ & $8.0(20)$ \\
$(46)$ & Kagoshima & $12(28)$ & $6.9(32)$ & $13(25)$ & $7.5(34)$ \\
$(47)$ & Okinawa & $8(37)$ & $6.2(36)$ & $10(32)$ & $7.5(32)$ \\
Total & & $1163-$ & $9.1-$ & $1061-$ & $8.3-$ \\
\hline
\end{tabular}

Note: Figures in parentheses indicate the ranking in terms of emissions volume

based emissions, followed by Tokyo (13), Aichi (23), Kanagawa (14), and Osaka (27). On the other hand, Tokyo (13) has the largest volume of consumption-based emissions, far higher than the next-highest prefectures of Kanagawa (14), Osaka (27), Aichi (23), and Hokkaido (1). Focusing on per capita emissions, Fukui (18) has the largest volume of production-based emissions, followed by Fukushima (7), Oita (44), Okayama (33), and Yamaguchi (35); the ranking for consumption-based emissions is Tokyo (13), Mie (24), Aichi (23), Ishikawa (17), and Ehime (38).

These results imply that emissions volume and the relative ranking for a given prefecture differ significantly depending on the criteria for calculating emissions. In 24 prefectures, production-based emissions are larger than consumption-based emissions, whereas in the remaining 23 prefectures, the inverse is true. Figure 4 plots productionand consumption-based emissions at the prefectural level based on the framework presented in Table 2. In this figure, the horizontal axis represents production-based emissions and the vertical axis, consumption-based emissions. The more distant a marker is from the $45^{\circ}$ line in the figure, the larger the imbalance in the two categories of emissions. Consumption-based emissions are much larger than production-based emissions in Tokyo (13), while Fukui (18) shows an opposite trend.

Figure 4 shows that there is less prefectural variation in consumption-based emissions than in production-based emissions. The former varies mostly depending on per capita total expenditures on final demand and the latter on industrial structure and per

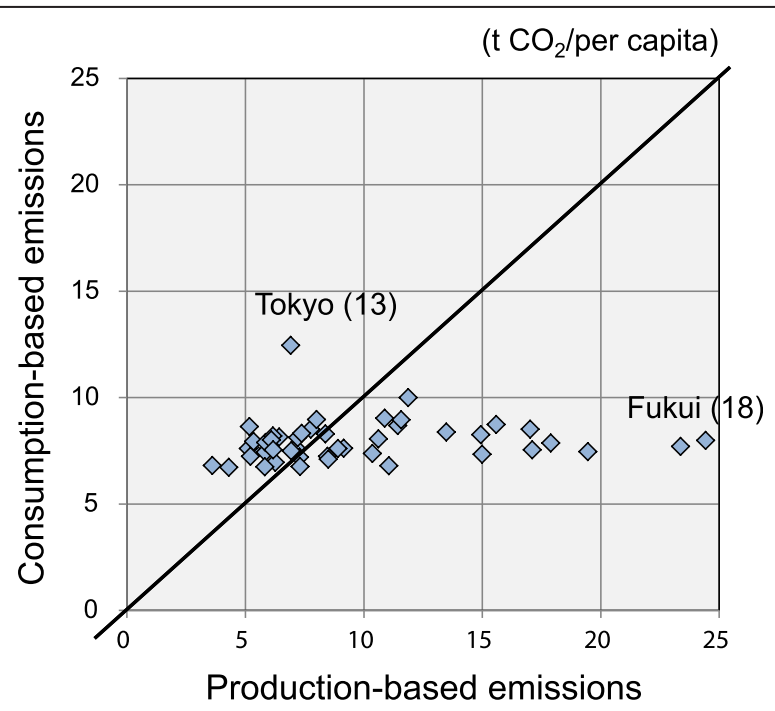

Fig. 4 Differences between production- and consumption-based emissions in each prefecture 
capita total industrial output. Emissions intensities show wide variations among industries, with an approximately 1500-fold difference between the largest and smallest intensities in the 80-sector classification. Therefore, we expect that differences in industrial structure are the largest contributor to the large variation in productionbased emissions. Figure 4 also shows large differences between the two emissions categories in many prefectures, indicating the importance of investigating carbon footprints at the sub-national level.

Next, we address the prefectures' carbon footprints. As defined in Eq. (13) in Section 3, a carbon footprint is regarded as consumption-based emissions, excluding direct household emissions. Figure 5 shows a breakdown of the carbon footprints generated by each prefecture within its boundaries and throughout the rest of Japan. Carbon footprints generated in the rest of Japan are interpreted as carbon leakage. The ratio of carbon leakage to total carbon footprint averages $51.7 \%$ at the prefectural level, ranging from $34.8 \%$ (Okinawa (47)) to $79.8 \%$ (Shiga (25)). The results reveal that carbon leakage is relatively large and differs significantly across prefectures. Therefore, it is essential to identify carbon leakage more quantitatively to estimate the prefectures' carbon footprints.

\subsection{Carbon leakage and economic leakage: the case of Tokyo}

In this subsection, we focus on the carbon footprint derived from final demand in Tokyo. Tokyo directly and indirectly induces production and emissions in not only Tokyo but also other prefectures. It is clear that Tokyo's influence on other prefectures is significant, but the influence differs in terms of economic or emissions-related effects. These differences are not always clearly identified at the prefectural level. Table 3 shows the carbon footprint and induced production derived from final demand for several industrial sectors in Tokyo for which the differences are large or notable.

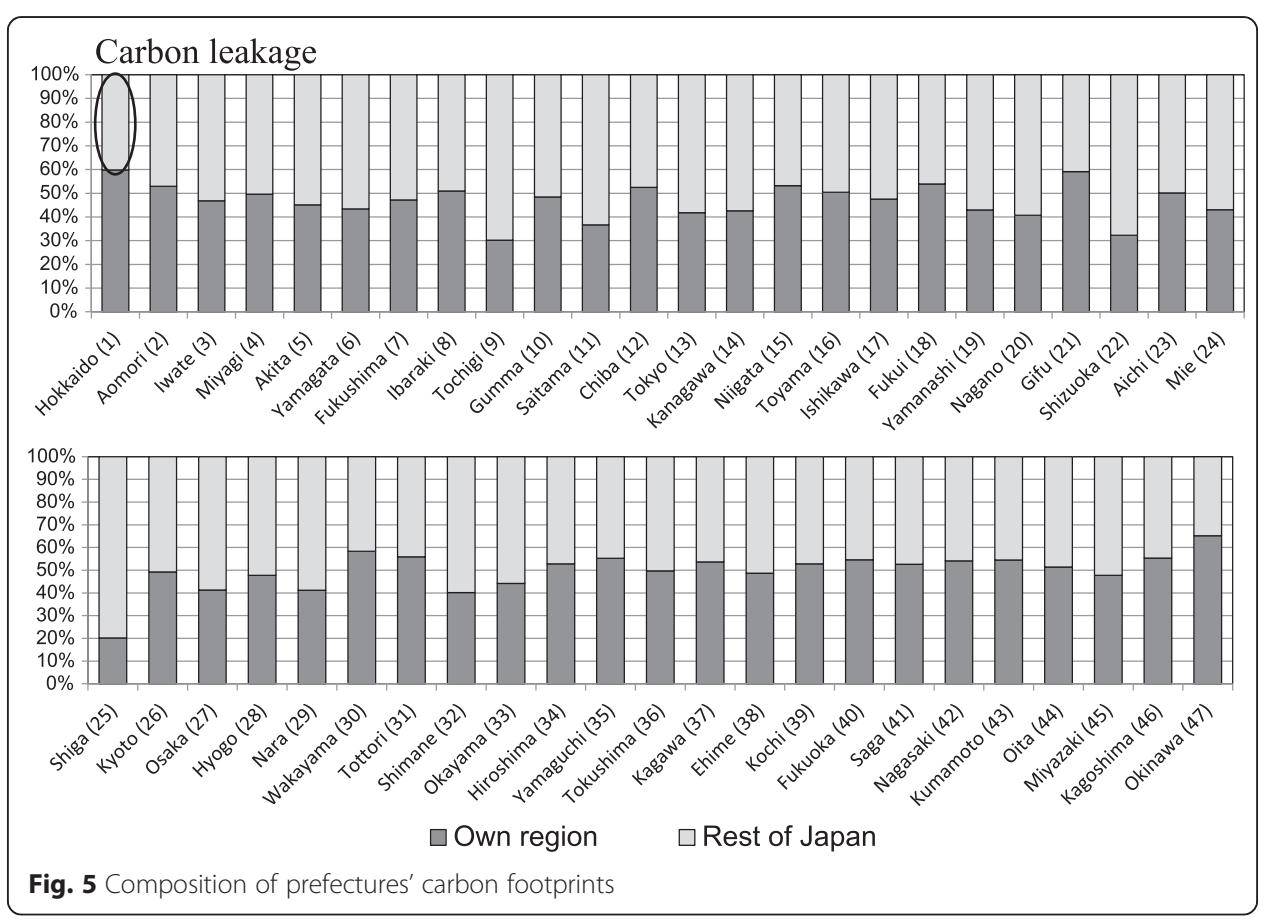


Table 3 Tokyo's carbon footprint and induced production (in \%)

\begin{tabular}{|c|c|c|c|c|c|c|c|}
\hline & & \multicolumn{2}{|c|}{$\begin{array}{l}\text { Agriculture, forestry } \\
\text { and fisheries (1) }\end{array}$} & \multicolumn{2}{|l|}{ Fabric (7) } & \multicolumn{2}{|c|}{$\begin{array}{l}\text { Metal products for construction } \\
\text { and architecture (36) }\end{array}$} \\
\hline & & $\begin{array}{l}\text { Carbon } \\
\text { footprint }\end{array}$ & $\begin{array}{l}\text { Induced } \\
\text { production }\end{array}$ & $\begin{array}{l}\text { Carbon } \\
\text { footprint }\end{array}$ & $\begin{array}{l}\text { Induced } \\
\text { production }\end{array}$ & $\begin{array}{l}\text { Carbon } \\
\text { footprint }\end{array}$ & $\begin{array}{l}\text { Induced } \\
\text { production }\end{array}$ \\
\hline (1) & Hokkaido & 8.85 & 9.34 & 0.50 & 0.47 & 2.51 & 1.47 \\
\hline (2) & Aomori & 2.45 & 2.61 & 0.10 & 0.09 & 0.68 & 0.34 \\
\hline (3) & Iwate & 1.79 & 1.96 & 0.10 & 0.13 & 0.26 & 0.70 \\
\hline (4) & Miyagi & 2.14 & 2.22 & 0.27 & 0.29 & 1.20 & 2.14 \\
\hline (5) & Akita & 1.55 & 1.52 & 0.26 & 0.14 & 0.25 & 0.40 \\
\hline (6) & Yamagata & 1.66 & 1.79 & 0.37 & 0.48 & 0.14 & 0.36 \\
\hline (7) & Fukushima & 3.57 & 2.26 & 2.51 & 0.60 & 1.85 & 1.09 \\
\hline (8) & Jbaraki & 3.97 & 3.52 & 2.70 & 2.05 & 8.04 & 5.91 \\
\hline (9) & Tochigi & 1.70 & 2.02 & 0.27 & 0.39 & $11.8^{\circ}$ & 2.76 \\
\hline (10) & Gumma & 1.79 & 1.94 & 1.55 & 1.91 & 0.62 & 1.75 \\
\hline (11) & Saitama & 1.06 & 1.33 & 1.20 & 1.82 & 1.01 & 3.22 \\
\hline (12) & Chiba & 5.66 & 4.54 & 3.40 & 1.90 & 13.51 & 8.32 \\
\hline (13) & Tokyo & 14.29 & 17.43 & 8.49 & 13.19 & 13.51 & 8.32 \\
\hline (14) & Kanagawa & 2.21 & 2.01 & 2.25 & 2.07 & 4.13 & 3.34 \\
\hline (15) & Niigata & 3.48 & 2.82 & 2.74 & 2.00 & 1.78 & 1.91 \\
\hline (16) & Toyama & 0.96 & 0.86 & 1.93 & 1.56 & 2.59 & 5.87 \\
\hline (17) & Ishikawa & 0.70 & 0.70 & 4.115 & 3.35 & 2.21 & 0.35 \\
\hline (18) & Fukui & 0.96 & 0.45 & 5.80 & 5.52 & 0.93 & 0.87 \\
\hline (19) & Yamanashi & 0.59 & 0.68 & 0.61 & 0.46 & 0.57 & 1.32 \\
\hline (20) & Nagano & 2.26 & 2.19 & 0.61 & 0.46 & 0.57 & 1.32 \\
\hline (21) & Gifu & 0.78 & 0.79 & 4.03 & 5.00 & 0.86 & 1.86 \\
\hline (22) & Shizuoka & 2.51 & 2.61 & 12.72 & 13.22 & 7.01 & 5.99 \\
\hline (23) & Aichi & 2.51 & 2.61 & 12.72 & 13.22 & 7.01 & 5.99 \\
\hline (24) & Mie & 1.52 & 1.43 & 1.93 & 1.63 & 0.92 & 2.25 \\
\hline (25) & Shiga & 0.58 & 0.76 & 3.26 & 4.49 & 0.47 & 2.42 \\
\hline (26) & Kyoto & 0.60 & 0.66 & 3.09 & 3.22 & 0.42 & 0.66 \\
\hline (27) & Osaka & 1.56 & 2.01 & 5.47 & 7.70 & 4.54 & 8.70 \\
\hline (28) & Hyogo & 1.51 & 1.53 & 3.30 & 3.08 & 6.75 & 5.33 \\
\hline (29) & Nara & 0.36 & 0.43 & 0.62 & 0.86 & 0.20 & 0.87 \\
\hline (30) & Wakayama & 1.60 & 1.57 & 3.95 & 5.20 & 2.71 & 1.55 \\
\hline (31) & Tottori & 0.48 & 0.52 & 0.12 & 0.13 & 0.05 & 0.12 \\
\hline (32) & Shimane & 0.78 & 0.69 & 0.51 & 0.38 & 0.32 & 0.35 \\
\hline (33) & Okayama & 1.38 & 1.14 & 2.90 & 2.73 & 6.67 & 2.34 \\
\hline (34) & Hiroshima & 1.07 & 0.89 & 2.04 & 1.85 & 9.44 & 4.11 \\
\hline (35) & Yamaguchi & 1.32 & 0.86 & 2.43 & 1.16 & 1.97 & 1.73 \\
\hline (36) & Tokushima & 1.11 & 1.00 & 1.01 & 0.87 & 0.40 & 0.35 \\
\hline (37) & Kagawa & 0.90 & 0.94 & 0.39 & 0.41 & 1.00 & 1.96 \\
\hline (38) & Ehime & 2.22 & 0.91 & 4.22 & 2.63 & 0.65 & 1.96 \\
\hline (39) & Koch & 0.94 & 1.01 & 2.21 & 2.27 & 0.11 & 0.97 \\
\hline (40) & Fukuoka & 2.19 & 2.29 & 0.59 & 0.67 & 5.25 & 3.20 \\
\hline (41) & Saga & 1.44 & 1.37 & 0.33 & 0.18 & 0.31 & 0.34 \\
\hline (42) & Nagasaki & 1.99 & 1.87 & 0.39 & 0.10 & 0.30 & 0.20 \\
\hline
\end{tabular}


Table 3 Tokyo's carbon footprint and induced production (in \%) (Continued)

\begin{tabular}{|c|c|c|c|c|c|c|c|}
\hline (43) & Kumamoto & 2.03 & 2.04 & 0.41 & 0.45 & 0.46 & 1.39 \\
\hline (44) & Oita & 1.71 & 1.52 & 0.89 & 0.66 & 4.12 & 1.32 \\
\hline (45) & Miyazaki & 2.23 & 2.32 & 1.35 & 0.76 & 0.27 & 0.25 \\
\hline (46) & Kagoshima & 0.52 & 0.52 & 0.45 & 0.44 & 0.19 & 0.27 \\
\hline (47) & Okinawa & 0.58 & 0.53 & 0.08 & 0.08 & 0.17 & 0.19 \\
\hline \multicolumn{2}{|c|}{ Total (\%) } & 100 & 100 & 100 & 100 & 100 & 100 \\
\hline \multicolumn{2}{|c|}{$\begin{array}{l}\text { Total ( } 1000 \mathrm{t} \mathrm{CO}_{2} \text { or } \\
\text { billion yen) }\end{array}$} & 1180 & 814 & 180 & 91 & 60 & 30 \\
\hline & & & & \multicolumn{2}{|c|}{$\begin{array}{l}\text { House rent (imputed house rent) } \\
\text { (66) }\end{array}$} & \multicolumn{2}{|c|}{ Total final demand } \\
\hline & & & & $\begin{array}{l}\text { Carbon } \\
\text { footprint }\end{array}$ & $\begin{array}{l}\text { Induced } \\
\text { production }\end{array}$ & $\begin{array}{l}\text { Carbon } \\
\text { footprint }\end{array}$ & $\begin{array}{l}\text { Induced } \\
\text { production }\end{array}$ \\
\hline (1) & Hokkaido & & & 2.26 & 0.12 & 1.72 & 1.13 \\
\hline (2) & Aomori & & & 0.48 & 0.02 & 0.35 & 0.24 \\
\hline (3) & Iwate & & & 0.52 & 0.03 & 0.31 & 0.33 \\
\hline (4) & Miyagi & & & 0.91 & 0.07 & 0.72 & 0.63 \\
\hline (5) & Akita & & & 0.43 & 0.02 & 0.54 & 0.20 \\
\hline (6) & Yamagata & & & 0.21 & 0.02 & 0.54 & 0.20 \\
\hline (7) & Fukushima & & & 3.83 & 0.07 & 5.65 & 0.90 \\
\hline (8) & Ibaraki & & & 4.23 & 0.12 & 2.82 & 1.18 \\
\hline (9) & Tochigi & & & 0.96 & 0.05 & 0.57 & 0.73 \\
\hline (10) & Gumma & & & 0.83 & 0.06 & 0.58 & 0.83 \\
\hline (11) & Saitama & & & 2.73 & 0.25 & 1.55 & 1.81 \\
\hline (12) & Chiba & & & 5.41 & 0.19 & 5.51 & 1.65 \\
\hline (13) & Tokyo & & & 31.74 & 96.54 & 41.78 & 65.68 \\
\hline (14) & Kanagawa & & & 3.16 & 0.25 & 2.98 & 2.73 \\
\hline (15) & Niigata & & & 2.29 & 0.06 & 2.77 & 0.67 \\
\hline (16) & Toyama & & & 0.59 & 0.04 & 0.57 & 0.30 \\
\hline (17) & Ishikawa & & & 0.42 & 0.03 & 0.52 & 0.28 \\
\hline (18) & Fukui & & & 1.61 & 0.03 & 2.20 & 0.27 \\
\hline (19) & Yamanashi & & & 0.21 & 0.02 & 0.18 & 2.26 \\
\hline (20) & Nagano & & & 0.88 & 0.05 & 1.22 & 0.76 \\
\hline (21) & Gifu & & & 1.18 & 0.07 & 0.70 & 0.53 \\
\hline (22) & Shizuoka & & & 2.55 & 0.15 & 2.48 & 1.95 \\
\hline (23) & Aichi & & & 4.81 & 0.23 & 3.11 & 3.02 \\
\hline (24) & Mie & & & 1.64 & 0.08 & 1.24 & 0.90 \\
\hline (25) & Shiga & & & 0.82 & 0.05 & 0.39 & 0.59 \\
\hline (26) & Kyoto & & & 0.71 & 0.07 & 0.65 & 0.70 \\
\hline (27) & Osaka & & & 3.24 & 0.46 & 2.56 & 3.36 \\
\hline (28) & Hyogo & & & 2.72 & 0.14 & 1.86 & 1.54 \\
\hline (29) & Nara & & & 0.12 & 0.02 & 0.13 & 0.21 \\
\hline (30) & Wakayama & & & 0.96 & 0.03 & 0.72 & 0.26 \\
\hline (31) & Tottori & & & 0.10 & 0.01 & 0.11 & 0.13 \\
\hline (32) & Shimane & & & 0.59 & 0.02 & 0.74 & 0.16 \\
\hline (33) & Okayama & & & 1.95 & 0.07 & 1.45 & 0.65 \\
\hline (34) & Hiroshima & & & 2.41 & 0.10 & 1.75 & 0.81 \\
\hline
\end{tabular}


Table 3 Tokyo's carbon footprint and induced production (in \%) (Continued)

\begin{tabular}{|c|c|c|c|c|c|}
\hline (35) & Yamaguchi & 2.20 & 0.05 & 1.39 & 0.47 \\
\hline (36) & Tokushima & 0.57 & 0.03 & 0.65 & 0.21 \\
\hline (37) & Kagawa & 0.58 & 0.04 & 0.44 & 0.27 \\
\hline (38) & Ehime & 1.03 & 0.06 & 0.94 & 0.43 \\
\hline (39) & Koch & 0.51 & 0.01 & 0.19 & 0.09 \\
\hline (40) & Fukuoka & 3.14 & 0.15 & 1.55 & 1.08 \\
\hline (41) & Saga & 0.53 & 0.01 & 0.67 & 0.19 \\
\hline (42) & Nagasaki & 0.64 & 0.01 & 1.00 & 0.21 \\
\hline (43) & Kumamoto & 0.44 & 0.03 & 0.30 & 0.30 \\
\hline (44) & Oita & 1.59 & 0.04 & 1.09 & 0.37 \\
\hline (45) & Miyazaki & 0.30 & 0.01 & 0.23 & 0.19 \\
\hline (46) & Kagoshima & 0.70 & 0.03 & 0.69 & 0.37 \\
\hline (47) & Okinawa & 0.29 & 0.02 & 0.23 & 0.11 \\
\hline \multicolumn{2}{|c|}{ Total (\%) } & 100 & 100 & 100 & 100 \\
\hline \multicolumn{2}{|c|}{ Total (1000 t Co 2 or billion yen) } & 1011 & 7974 & 130439 & 117219 \\
\hline
\end{tabular}

The $\mathrm{CO}_{2}$ emitted in other prefectures is described as carbon leakage. Similarly, the production induced in other prefectures can be also described as "economic leakage" because Tokyo "leaks" economic activities into other prefectures through the economic repercussions of satisfying its final demand. We investigated carbon leakage and economic leakage induced by Tokyo's final demand within sectors to identify the differences in carbon and economic leakage. Table 3 shows the prefecture-country ratio of the carbon footprint and production induced by Tokyo's final demand.

First, we focus on leakages based on Tokyo's final demand from the agriculture, forestry, and fisheries sector (1). The carbon footprint generated by Tokyo accounts for $14.3 \%$ of the total amount in Japan. At the same time, $17.4 \%$ of the induced production is generated in Tokyo, which implies that its carbon leakage is greater than its economic leakage. Focusing on the breakdown by prefecture, Tokyo's carbon leakage is larger than its economic leakage to Fukushima (7) and Chiba (12), while the inverse is true for Hokkaido (1) and Osaka (27). This offers a concrete example of how Tokyo's influence on the economy and environment differs across prefectures.

In the fabric (7) sector, $8.5 \%$ of the carbon footprint and $13.2 \%$ of the monetary output are generated in Tokyo. Tokyo's final demand generates a greater carbon leakage than economic leakage around its own prefecture. Table 3 also shows that Tokyo generates a relatively large carbon leakage to western Japan and a large economic leakage around its own prefecture when considering metal products for construction and architecture (36).

In the house rent (imputed house rent) (66) sector, $96.5 \%$ of induced production is generated in Tokyo, meaning that there is almost no economic leakage. In contrast, the carbon footprint generated in Tokyo accounts for only $31.7 \%$ of the national total, and Tokyo leaks carbon to many prefectures. Therefore, there are large differences between carbon and economic leakage in this sector.

Finally, we verify the differences between carbon and economic leakage based on total final demand in Tokyo. These are also estimated using the METI-compiled interregional IO table, which is segmented into nine regions. Table 4 compares the results 
Table 4 Comparison of results between our original MRIO tables and the METI table (in \%)

\begin{tabular}{|c|c|c|c|c|}
\hline & \multicolumn{2}{|c|}{$\begin{array}{l}\text { Estimated by the table } \\
\text { constructed in this paper }\end{array}$} & \multicolumn{2}{|c|}{$\begin{array}{l}\text { Estimated by the table } \\
\text { compiled by METI }\end{array}$} \\
\hline & $\begin{array}{l}\text { Carbon } \\
\text { footprint }\end{array}$ & $\begin{array}{l}\text { Induced } \\
\text { production }\end{array}$ & $\begin{array}{l}\text { Carbon } \\
\text { footprint }\end{array}$ & $\begin{array}{l}\text { Induced } \\
\text { production }\end{array}$ \\
\hline Hokkaido & 1.72 & 1.13 & 1.84 & 1.13 \\
\hline \multicolumn{5}{|l|}{ Including prefecture (1) } \\
\hline Tohoku & 7.79 & 2.61 & 8.13 & 2.63 \\
\hline \multicolumn{5}{|c|}{ Including prefectures (2), (3), (4), (5), (6), and (7) } \\
\hline Kanto & 62.42 & 78.25 & 64.90 & 80.26 \\
\hline \multicolumn{5}{|c|}{$\begin{array}{l}\text { Including prefectures (8), (9), (10), (11), (12), } \\
(13),(14),(15),(19),(20), \text { and (22) }\end{array}$} \\
\hline Chubu & 6.13 & 5.03 & 6.92 & 5.10 \\
\hline \multicolumn{5}{|c|}{ Including prefectures (16), (17), (21), (23), and (24) } \\
\hline Kinki & 8.51 & 6.92 & 8.01 & 5.79 \\
\hline \multicolumn{5}{|c|}{ Including prefectures (18), (25), (26), (27), (28), (29), and (30) } \\
\hline Chugoku & 5.44 & 2.23 & 4.85 & 2.17 \\
\hline \multicolumn{5}{|c|}{ Including prefectures (31), (32), (33), (34), and (35) } \\
\hline Shikoku & 2.22 & 1.00 & 1.68 & 0.83 \\
\hline \multicolumn{5}{|c|}{ Including prefectures (36), (37), (38), and (39) } \\
\hline Kyushu & 5.53 & 2.71 & 3.47 & 2.01 \\
\hline \multicolumn{5}{|c|}{ Including prefectures (40), (41), (42), (43), (44), (45), and (46) } \\
\hline Okinawa & 0.23 & 0.11 & 0.20 & 0.09 \\
\hline \multicolumn{5}{|l|}{ Including prefecture (47) } \\
\hline Total (\%) & 100 & 100 & 100 & 100 \\
\hline Total (1000 t $\mathrm{CO}_{2}$ or billion yen) & 130,439 & 117,219 & 128,071 & 118,482 \\
\hline
\end{tabular}

Note: The table shows carbon footprint and induced production derived from total final demand in Tokyo (13)

obtained from our MRIO table to the METI table. Although not completely consistent because aggregation levels of regions and sectors vary between the two tables, both sets of figures show that Tokyo generates a larger induced output than carbon footprint in Kanto while the remaining eight regions show the opposite trend. However, when we investigate this for each of the prefectures included in Kanto, as shown in the right-hand side of Table 3, we find that a larger carbon footprint than induced production is generated in Ibaraki (8), Chiba (S12), Kanagawa (14), Niigata (15), Nagano (20), and Shizuoka (22). These prefectures thus show the opposite tendency to Kanto as a whole.

Table 3 shows that the carbon footprint generated in Tokyo accounts for $41.8 \%$ of the national total, while $65.7 \%$ of induced production is generated in Tokyo. Table 3 also confirms that Tokyo's carbon leakage is larger than its economic leakage.

\section{Conclusions}

This paper, motivated by increasing concern on the part of sub-national governments over global warming, analyzed prefectural carbon footprints in Japan. We constructed an original MRIO table, which we made freely available online, using data from 2005 that consisted of all prefectures in Japan and 80 industrial sectors; by applying a non-survey technique, we determined the structure of emissions at the prefectural level. The 
emissions structure was compiled considering both consumer and producer responsibility. We also investigated the carbon footprint generated by final demand in Tokyo and identified Tokyo's carbon leakage and economic leakage to prefectures across Japan.

Our analyses revealed that in many prefectures, production-based emissions differ significantly from consumption-based emissions. There were larger variations in production-based emissions than in consumption-based emissions. We also found that the ratio of carbon leakage to carbon footprint averages $51.7 \%$ at the prefectural level and ranges from $34.8 \%$ (Okinawa) to $79.8 \%$ (Shiga).

Although various activities in prefectures affect both types of emissions, productionbased emissions are strongly influenced by policies enacted to attract industry, the spatial division of labor, and production technology at the prefectural level. Consumption-based emissions, in contrast, are shaped by consumer behaviors, such as consumption patterns and environmental consciousness, as well as the scale of final demand. Based on these results, we conclude that environmental policies within each prefecture should divide emissions sources and address them by considering producer and consumer responsibility.

We also investigated the carbon footprint and production induced by Tokyo, Japan's largest metropolitan area. It is clear that Tokyo's influence on other prefectures is significant, but this influence differs between economy and emissions. We illustrated how these differences are not accurately identified at the regional level by comparing Tables 3 and 4. Our analysis noted differences at the prefectural level and found certain prefectures benefitting from or suffering a loss in terms of carbon footprint and induced production due to final demand in Tokyo. The results indicate that Tokyo's influence in terms of carbon and economic leakage varies significantly from prefecture to prefecture and that, as a whole, Tokyo has a larger carbon leakage than economic leakage.

The prefectural variation in production-based emissions results from the industrial distribution promoted by each industry at the national level; prefectural governments' policies have not strongly influenced industrial activities in the past. This suggests that prefectural governments are less responsible for production-based emissions than is the national government and have difficulty in directly addressing these.

To implement effective emissions reduction policies, prefectures should thus focus on addressing consumption-based emissions from the viewpoint of consumer responsibility. This is because Japan's prefectures can exercise relatively more discretion when framing environmental policies related to the residential sector. To reduce consumption-based emissions by promoting environmentally friendly consumer behavior, it is important to inform consumers of how regional characteristics affect carbon footprints. The methodology and results presented in this paper can help to do this.

Before closing, we will note some topics for future research. In constructing its MRIO table, this paper adopted a method that requires limited data to disaggregate industrial sectors and can be widely applied. As a result, however, it was necessary to sacrifice some precision in the constructed table. Interregional trade was estimated using the RAS method based on output shares; finding alternatives to this approach is an area in need of future research. In order to facilitate more reliable analyses of carbon footprints at the regional level, it is necessary to develop a method, as in Ishikawa and Miyagi [9], for constructing an interregional IO table with more accurate estimations of interregional trade at a detailed industry level. 
With respect to our carbon footprint analysis, there are some shortcomings that should be noted. First, this paper did not consider the carbon footprint induced in foreign countries by Japanese final demand. Second, this paper did not alter emissions intensities for a given industry depending on the prefecture and therefore did not address regional differences in emissions intensities. Third, our analysis was confined to identifying the current status of prefectural emissions and did not extend to analyzing prefectural policies related to global warming.

Although these issues remain to be addressed, this paper has expanded the scope of IO analysis of carbon footprints at the regional level; its approach can be applied to undertake quantitative analysis of global warming policies considered by prefectures.

\section{Endnotes}

${ }^{1}$ Generally speaking, carbon leakage refers to the phenomenon wherein overseas emissions (especially those in countries with less strict environmental regulations) increase because of emissions restrictions in a given country. However, this study considers carbon leakage to refer to the more general case of economic activity in one country (region) leading to induced emissions in another country (region) through the division of labor and trade.

${ }^{2} \mathrm{IO}$ models linking multiple regions are classified into interregional and multiregional IO models. The former consists of a complete set of intra- and interregional data and is often labeled "Isard type." The latter links single-region models using simplifications and is often labeled "Chenery-Moses type" or "Leontief-Strout type" (see pp. 76-101 of Miller and Blair [12] for details of the two models). This paper mainly focuses on MRIO as an IO model linking multiple regions, as compared with a single-region input-output (SRIO) model.

${ }^{3}$ In a special issue of Economic Systems Research devoted to carbon footprints, Minx et al. [13] and Wiedmann [14] summarized the applications of the IO model to carbon footprint analysis, including a brief description of the historical context.

${ }^{4}$ Peter et al. [15] proposed a method to construct environmentally extended MRIO tables using the database of the Global Trade Analysis Project (G-TAP) and used the constructed table for analysis. The authors also proposed six key questions regarding the construction of an MRIO table using the G-TAP database. Similarly, Muñoz and Steininger [16] constructed MRIO tables from the G-TAP database in order to account for Austria's $\mathrm{CO}_{2}$ responsibility due to consumption-based emissions.

${ }^{5}$ Gallego and Lenzen [17] present a discussion related to producer and consumer responsibility for environmental burdens and attempt to construct a framework that uses an IO model to assign producer and consumer responsibility.

${ }^{6}$ Some prefectural SRIO tables do not distinguish between foreign and domestic exports. In such cases, we divided the given figures using data from SRIO tables for the nine regions, as compiled by METI. The same procedure was followed for imports, where necessary.

${ }^{7}$ It has been reported that when the diagonal elements are set to zero, the RAS calculation is unable to converge or requires a large number of iterations to converge. However, our calculation easily converged, presumably because the diagonal elements of our matrix account for only $1 / 47$ th of all elements. 
${ }^{8}$ For an economic interpretation of the RAS procedure, see pp. 328-329 of Millar and Blair [12] for a basic overview and Lahr and Mesnard [11] for more detailed coverage.

${ }^{9} \mathrm{Cite}$ this paper when reporting analytical results or other studies that use the table at a conference or in an article.

${ }^{10}$ This paper uses the $\mathrm{CO}_{2}$ emissions coefficients of Nansai and Moriguchi [18], who calculate the emissions coefficients at the national level in Japan. Therefore, this paper does not alter the emissions coefficient for a given sector across regions.

\section{Additional files}

Additional file 1: Constructed MRIO table (part1).

Additional file 2: Constructed MRIO table (part2).

Additional file 3: Constructed MRIO table (part3).

Additional file 4: Constructed MRIO table (part4).

Additional file 5: Constructed MRIO table (part5).

Additional file 6: Constructed MRIO table (part6).

Additional file 7: Constructed MRIO table (part7).

Additional file 8: Constructed MRIO table (part8).

Additional file 9: Constructed MRIO table (part9).

Competing interests

The authors declare that they have no competing interests.

\section{Acknowledgments}

The first version of this paper was presented at the 19th International Input-Output Conference, held in Alexandria, USA, from 13th to 17th June 2011. The authors are grateful to anonymous referees for their useful comments and suggestions for revising the paper.

\section{Author details}

${ }^{1}$ Faculty of Global Business, Osaka International University, 6-21-57 Tohdacho, 570-8555 Moriguchi, Osaka, Japan.

${ }^{2}$ Faculty of Economics, Kyushu University, 6-19-1 Hakozaki, 812-8581 Higashi-ku, Fukuoka, Japan. ${ }^{3}$ Faculty of Business and Commerce, Tokyo International University, 1-13-1 Matoba-kita, 350-1197 Kawagoe, Saitama, Japan.

Received: 16 June 2014 Accepted: 20 May 2015

Published online: 18 June 2015

\section{References}

1. Hasegawa R (2009) An examination of estimation methods employed for determining $\mathrm{CO}_{2}$ emissions at the prefectural level in Japan. Journal of Applied Input-Output Analysis 15:1-20

2. Kudoh Y, Kondo Y, Matsuhashi K, Kobayashi S, Moriguchi Y (2004) Current status of actual fuel-consumptions of petrol-fuelled passenger vehicles in Japan. Appl Energy 79:291-308

3. Vringer K, Benders R, Wilting H, Brink C, Drissen E, Nijdam D, Hoogervorst N (2010) A hybrid multi-region method (HMR) for assessing the environmental impact of private consumption. Ecol Econ 69(12):2510-2516

4. Ackerman F, Ishikawa M, Suga M (2007) The carbon content of Japan-US trade. Energy Policy 35(9):4455-4462

5. Su B, Ang BW (2011) Multi-region input-output analysis of $\mathrm{CO}_{2}$ emissions embodied in trade: the feedback effects. Ecol Econ 71:42-53

6. Su B, Ang BW (2010) Input-output analysis of $\mathrm{CO}_{2}$ emissions embodied in trade: the effects of spatial aggregation. Ecol Econ 70(1):10-18

7. Zhou X, Imura H (2011) How does consumer behavior influence regional ecological footprints? An empirical analysis for Chinese regions based on the multi-region input-output model. Ecol Econ 71:171-179

8. Isard W (1951) Interregional and regional input-output analysis: a model of a space economy. Rev Econ Stat 33:318-328

9. Ishikawa Y, Miyagi T (2004) The construction of a 47-region inter-regional input-output table and inter-regional interdependence analysis at prefecture level in Japan. ERSA conference papers, ersa04: 432, European Regional Science Association, University of Porto, Porto, Portugal.

10. Jacobsen HK (2000) Energy demand, structural change and trade: a decomposition analysis of the Danish manufacturing industry. Econ Syst Res 12(3):319-343

11. Lahr ML, Mesnard LD (2004) Biproportional techniques in input-output analysis: table updating and structural analysis. Econ Syst Res 16(2):115-134

12. Miller RE, Blair PD (2009) Input-output analysis: foundations and extensions, 2nd edn. Cambridge University Press, Cambridge 
13. Minx J, Wiedmann T, Wood R, Peters G, Lenzen M, Owen A, Scott K, Barret J, Hubacek K, Baiocchi G, Paul A, Dawkins E, Briggs J, Guan D, Suh S, Ackerman F (2009) Input-output analysis and carbon foot-printing: an overview of applications. Econ Syst Res 21(3):187-216

14. Wiedmann T (2009) Editorial: Carbon footprint and input-output analysis—an introduction. Econ Syst Res 21(3):175-186

15. Peters G, Andrew R, Lennox J (2011) Constructing an environmentally-extended multi-regional input-output table using the GTAP database. Econ Syst Res 23(2):131-152

16. Muñoz P, Steininger KW (2010) Austria's $\mathrm{CO}_{2}$ responsibility and the carbon content of its international trade. Ecol Econ 69(10):2003-2019

17. Gallego B, Lenzen M (2005) A consistent input-output formulation of shared producer and consumer responsibility. Econ Syst Res 17(4):365-391

18. Nansai K, Moriguchi $Y$ (2012) Embodied energy and emission intensity data for Japan using input-output tables (3EID): For 200510 table (Beta+ version). CGER, National Institute for Environmental Studies, Japan. http://www.cger.nies.go.jp/publications/report/d031/index.html. Accessed 18 March 2015.

Submit your manuscript to a SpringerOpen ${ }^{\circ}$ journal and benefit from:

- Convenient online submission

- Rigorous peer review

- Immediate publication on acceptance

- Open access: articles freely available online

- High visibility within the field

- Retaining the copyright to your article

Submit your next manuscript at $>$ springeropen.com 